\title{
THE DISCUSSION OF HUMAN NATURE IN THE 5TH AND 4TH CENTURIES BCE IN THE SO-CALLED SOPHISTIC MOVEMENT
}

\author{
ZBIGNIEW NERCZUK \\ Nicolaus Copernicus University, Toruń (Poland) \\ zibbi@umk.pl
}

\begin{abstract}
The paper discusses the debate on the human nature in the sophistic thought. Focusing on the "nature - culture" controversy it presents the evolution of the views of the sophists: from Protagoras' optimistic contention of the progress of mankind and his appraisal of culture to its criticism and the radical turn to nature in Antiphon, Hippias, Trasymachos, and Callicles. The paper aims at presenting the analysis of the ongoing discussion, with the stress laid on reconstruction of the arguments and concepts as well as the attitudes that are associated with various positions of this debate.

KEYWORDS: Greek Philosophy, Presocratic philosophy, the sophists, Plato, nature-culture controversy.
\end{abstract}

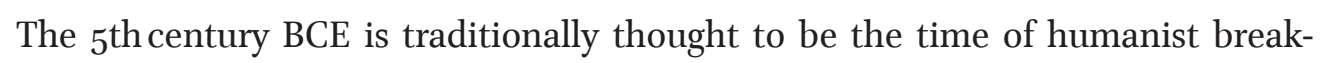
through in Greek thought, which took a more systematic and innovative approach to issues related to man and man's social life. ${ }^{1}$ The view of this radical humanistic shift, which took place in the fifth century BCE had become prevailing already in late antiquity and was re-established in modern scholarship in the fundamental works of the German historians such as E. Zeller ${ }^{2}$, F. Ueberweg (1876), H. Diels ${ }^{3}$ and W. Nestle. ${ }^{4}$ Nowadays, this view is contested by many scholars, and there is evidence that the sophists such as Protagoras, Gorgias, Hippias, Polos, Prodicus, Alcidamas, Antiphon, and Critias were continuously concerned

\footnotetext{
${ }^{1}$ W. Nestle (1940) 263 .

${ }^{2}$ E. Zeller (1869).

${ }^{3}$ H. Diels (1884) $343^{-68 .}$

${ }^{4}$ W. Nestle (1940). W. Nestle (1922). 
with the problems introduced by the Presocratic philosophy of nature. ${ }^{5}$ The difference between the sophists and their Presocratic predecessors is not that these sophists have completely changed the subject of their interests, but rather that their concern with the naturalistic tradition and the transformative answers given to the old questions were the basis and the starting point of the "ethical" and "rhetorical" part of their intellectual activity. ${ }^{6}$

The preserved testimonies suggest that in this period the problems of philosophical anthropology and ethics drew the attention of the representatives of the so-called sophistic movement, Socrates, members of the Hippocratic school of medicine, Democritus as well as orators, historians, and playwrights. ${ }^{7}$

The objective of these anthropological enquiries was to identify the true essence of man, that is the human "nature" which was derived by the sophists from the Hippocratic medicine. ${ }^{8}$ On the one hand, the philosophical tradition of natural philosophy understood man as a biological creature, a part of the world of nature. On the other hand, travels and encounters with non-Greek civilizations, ${ }^{9}$ combined with social and political changes taking place in Athens in the $5^{\text {th cen- }}$ tury $\mathrm{BC},{ }^{10}$ inspired a new view of man, who was now seen from the perspective of man-made progress, that is from the perspective of his own cultural and technical

\footnotetext{
${ }^{5}$ G. B. Kerferd (1981).

${ }^{6}$ W. K. C. Guthrie (1969) 186: "He (i.e. Protagoras) was in the vanguard of the humanistic reaction against the natural philosophers, whose contradictory speculations were bringing them into disrepute among practical men - each one, as Gorgias said, claiming to possess the secret of the universe, but in fact only pitting one opinion against another, each more incredible than the last."
}

${ }^{7}$ L. Jansen, Ch. Jedan (2010).

${ }^{8}$ W. Jaeger (1971) 6: "In this, as in much else, both the sophists and Thucydides were influenced by contemporary medicine, which had discovered the idea of human nature and based all its work upon it."

${ }^{9}$ G. B. Kerferd (1981) 112: "Human laws, norms and habits of behaviour vary from community to community, and the more widely Greeks travelled in the ancient world the more apparent this became. Herodotus, himself a considerable traveler, seems to have set himself the task of collecting and describing the customs of Scythians, Persians, Lydians, Egyptians and others. He was not the first to do so, being preceded by Hecataeus of Miletus early in the fifth century. The second chapter of the Dissoi Logoi at sometime after the end of the fifth century uses systematic oppositions between the customs of different peoples, and references to a lost work of Aristotle testify to a continuing interest in Nomima Barbarika, the customs of the barbarians." Cf. A. Dihle (1981).

${ }^{10}$ C. Farrar (1988). 
achievements. ${ }^{11}$ Consequently, the anthropological discourse of the time saw the emergence of a dominant antithesis of nature and culture ("custom", "convention" $)^{12}$ and the onset of the battle fought between supporters of the standards determined by "nature" and the upholders of culture. ${ }^{13}$

The fundamental figure in the discussion was the "father of the sophists," Protagoras. In the dialogue in which the sophist is the main character, Plato puts into his mouth the well-known myth that allegorically presents comments on the nature of man, man's relation to nature, and the role of culture. ${ }^{14}$

As Protagoras says, after creating mortal creatures gods asked two Titans, Prometheus and Epimetheus, to distribute among different living creatures their appropriate qualities, with a view to ensuring their preservation. Epimetheus took on the job. As the less brainy of the two brothers, he provided the animals with everything he had at his disposal: strength, swiftness, size, fur, hoofs, etc. However, the foolish Epimetheus forgot about man, who was the only creature to be left naked and barefoot, weak and homeless. The misery of man was partially remedied by the wise Prometheus, who stole "the mechanical arts" and "fire" from Hephaestus and Athena. However, it was not until Zeus presented his gifts - "reverence and justice" - that humanity was finally fully equipped and man gained the advantage over all other living creatures. Men, upon Zeus' order, was equipped in equal measure with reverence and justice, thus gaining the ability to co-exist and live in society.

In Protagoras' story, nature is the starting point. The myth carefully unveils the consecutive stages of Epimetheus' work. Seemingly a simpleton, he fairly and wisely distributes gifts and balances the strengths: the weaker creatures are provided with swiftness so that they can escape from the stronger ones, the small ones are made to have numerous offspring, while the large and armed ones have just few offspring. However, it is just Epimetheus' omission that gives humanity

\footnotetext{
${ }^{11}$ Cf. the vivid discussion on the problem of craft (techne) which is closely related to the idea of progress: F. Heinimann (1961), J. Kube (1969).

${ }^{12}$ W. Windelband (1901) 74: "It dominates the entire philosophy of the period...". Cf. e.g. F. Heinimann (1945), W. K. C. Guthrie (1969), G.B. Kerferd (1981).

${ }^{13}$ The antithesis itself was known before, cf. G. B. Kerferd (1981) 112-13. On the concept of progress cf. G. B. Kerferd (1981) 125, E. R. Dodds (1973), J. Sihvola (1989).

${ }^{14}$ Plato, Prot., $320 \mathrm{c}$ sq. G. B. Kerferd (1981) 125 assumes that the myth is "in all probability based to some extent on doctrines of the historical Protagoras as published in such works as his treatise' On the Original State of Man." R. Winton (2008) 92 comments that "the 'Great Speech' of Protagoras in the dialogue that bears his name (320c-328d), [is] an analysis of the origins and nature of human society, of particular interest as offering one of the few systematic rationales of democracy to be found in ancient Greek texts."
} 
the quality which elevates men above the world of beasts. The arts stolen by Prometheus from gods and the gifts of Zeus introduce a new plan - a world of culture and civilization, of organized society relying on the ability to co-exist harmoniously.

In this way, the theft committed by Prometheus and the gifts from Zeus led humanity out of the animal state and created man, a member of society endowed with technical skills. Thanks to the arts, man - neglected and overlooked at distribution of natural qualities, although rooted in the animal world - managed to overcome this beastly element and rose above it. Owing to aidōs (which is reverence, respect, or esteem), man became a social being; he was endowed with the gift of morality: feeling ashamed, obeying gods, and respecting other people and the man-made order. ${ }^{15}$

The story Protagoras tells us is an expression of tremendous optimism, of pride taken in man, and a great praise of culture. ${ }^{16}$ Man, who becomes a human being and is no longer just a beast, leaves behind the brutish, the wild, and the primitive. He is equipped with such skills and devises such instruments that facilitate his unrestrained development. Protagoras' optimism makes the sophist proclaim triumphantly that humanity rose above the animal condition leaving behind the domain of savagery and becoming "good" and "noble". ${ }^{17}$

Thus, culture - the offspring of crafts, reverence, and justice - expresses humanity and substantiates the stepping out of the limits of the animal world. It seems that Protagoras believes that education (paideia) facilitates the making of "noble" men and the ideas formed by culture lead humanity to sublimity and

${ }^{15}$ C. Farrar (1988) 78: “...he (i.e. Protagoras) formulated an account of the human species which entailed (1) that civil society is a necessary feature of human existence."

${ }^{16}$ The issue of progress also appears in the text of Antiphon On Concord (Peri omonoias), which according to W. Aly (1929) 15o has many similarities with the concept of Protagoras. The problem of progress is also discussed by Prodicus in the work entitled Seasons (Ōrai) (cf. W. Nestle 1940, 351 sq.) and Critias (DK 88 B 25, 1-2).

${ }^{17}$ G. B. Kerferd $(1981,125)$ defines Protagoras' view as "Theory of Progress" as opposed to the pessimistic concept contained in Hesiod ("Theory of Decline") and the third concept known as "Cyclical Theory of History" (Myth of eternal recurrence). The state of primordial savagery is so pitying in the sophist's eyes that - as Protagoras claims - even the worst of the Athenians are still better than savages that the poet Pherecrates portrayed in his comedy Wild Men (Agrioi) (Pl., Prot., 327d). E. Dupréel (1948, 34 in footnote) even argues that Pherecrates's comedy could have been written on the canvas of Protagoras' treatise. 
make it possible to transgress the laws of nature..$^{18}$ Man is responsible for his own fate and is the creator of his world. ${ }^{19}$

As it seems, the so-called "apology of Protagoras", Plato's account of Protagoras' views presented in Theaetetus ${ }^{20}$, constitutes an appendix to the myth. The "apology", however, no longer describes the creation of culture and the world of men in terms of the myth. Emphasis is placed on practice, on the mechanisms decisive for the shaping of human reality.

The starting point for the discussion is the presentation of Protagoras' famous dictum: "man is the measure (metron) of all things: of those which are, that they are, and of those which are not, that they are not". ${ }^{21}$ This catchphrase, referred to as homo-mensura, determines a diversity of perspectives and introduces as many "worlds" as there are perceiving individuals. ${ }^{22}$ It eliminates any objectivity and introduces relativity, indeterminacy and subjectivity: all things always relate to something else, nothing is, but only appears. Consequently, the whole human reality is a result of an agreement between individuals: truth, good, justice, virtues, wisdom are just terms which do not refer to anything real.

\footnotetext{
${ }^{18}$ In contrast to the traditional myth, already present in Hesiod, of "five centuries of humanity", which contains a pessimistic vision of the continuous degradation of the world, progressing from the Golden Age to the Iron Age (Hesiod, Works and Days, 109 sq.), Protagoras presents an optimistic vision of human development based on a belief in progress. In this respect, Protagoras is close to the views presented by Socrates in Plato's Protagoras and Gorgias (both see the essence of humanity in culture and education). Perhaps this is why there are no great points of contention in the discussion on virtue conducted by Socrates and Protagoras, and there are many similar views, e.g. that man, thanks to culture, goes beyond his animal, primitive nature or their common interest in crafts as the tools for progress.

${ }^{19}$ The form of myth used by Protagoras is only a canvas of the naturalistic dimension that the description of man's transition from a state of ferocity to civilization brings with it. The free-thinking views of Protagoras, as evidenced by the beginning of the treatise on the gods, as well as the theories of Prodicus or Critias, in fact, remove the whole divine plan, so clearly visible in the poems of Homer and Hesiod and in the whole archaic Greek culture.

${ }^{20}$ Cf. Plato, Tht., $165 \mathrm{e} 7-168 \mathrm{c} 5$. There has been a long discussion about the attribution of the views presented by Plato in the dialogue Theaetetus under the name "secret doctrine". In my opinion, there are many arguments in favour of the opinion that Plato reproduced the historical views of Protagoras in the dialogue. Despite the controversy about the attribution of the "secret doctrine", the so-called "apology of Protagoras" is widely regarded as a faithful representation of Protagoras' views.

${ }^{21}$ J. Dillon, Gergel (2003) 10. On "man-measure" doctrine cf. G. B. Kerferd (1981) 86-87.

${ }^{22}$ Cf. U. Zilioli (2007).
} 
Protagoras must have realised that this view of a completely arbitrary world, which together with objectivity is deprived of truth, knowledge, wisdom and learning, poses a lot of difficulties. For how is it possible for people to cooperate in a situation when each man lives in his own "world"? And also how do the antilogical perspectives get reconciled between individuals? ${ }^{23}$

According to Protagoras, the decisive role in the process of unification of the view of reality is played by education and persuasion. Education (paideia) facilitates the reconciliation of different perspectives and makes possible creation of a certain common, uniform framework of cognition and interpretation. Protagoras' world, with the category of truth removed from it, is fully subjected to the power of persuasion. The inevitable contradiction of arguments is the starting point for a debate, for a clash of perspectives, for a search for the most powerful modes of persuasion (peithō), opening up the possibility to force an opinion that is "better", meaning more "effective" from a given perspective. This persuasive contest takes place on all levels of social organization, ranging from individuals to the states (civitas-mensura). ${ }^{24}$ According to Protagoras, sophists and orators are those who are able to form the opinions in individual souls and whole states, changing the views from "worse" to "better", thus determining the law and policies of entire states. $^{25}$

Although on Protagoras' view, the ideas governing the state situate themselves outside the categories of truth and falsehood and are based exclusively on the power of persuasion ${ }^{26}$, the sophist is again an optimist. He seems to believe in a prosperous world led by politicians looking after the state in the same way as doctors look after their patients, by such politicians who guard a specifically understood welfare and actually change ideas from "worse" to "better" for the state. Protagoras does not think that the extreme arbitrariness of the social world is destructive. Man is capable of rising above both animality and particularism.

After the splendid reign of Pericles, the faith in the autonomy of culture was undermined and collapsed during the Peloponnesian War. It seems that the historical events clearly demonstrated to the thinkers of the time that the faith in the triumphant march of humanity was an illusion which needs to be replaced with a reference to something that is more primeval than culture and that truly determines man. A group of the so-called "younger" sophists, which included fig-

${ }^{23}$ The response to Socrates' arguments is the above mentioned "apology of Protagoras".

${ }^{24} \mathrm{Pl}$. Tht., 167c: "Whatever seems right and honourable to state is really right and honourable to it, so long as it believes it to be so." (transl. by Fowler, 97).

${ }^{25} \mathrm{Pl}$., Tht. 167c: "but the wise man causes the good, instead of that which is evil to them in each instance, to be and seem right and honourable." (translated by Fowler p. 97).

${ }^{26} \mathrm{Pl} .$, Tht., $167 \mathrm{ac}$. 
ures such as Callicles, Thrasymachus, Polus, Antiphon gave a second thought to the issues of human nature contrasting the ideals of humanity and animality and consequently making a radical turn towards nature. ${ }^{27}$ In this new perspective, culture is just a façade hiding what really determines mankind and drives men to action. This real measure is nature.

These theses most certainly found their source in the study of history, observation of current events, ${ }^{28}$ and also in the interest in literature. ${ }^{29}$ This is suggested by Polus's delight in wealth and power of the "Great King" ${ }^{30}$ or his sincere admiration for the actions of Archelaus, the tyrant of Macedonia, who as a son of king Perdiccas and a slave woman murdered first his uncle, then a cousin, and finally his half-brother, whom he threw into a well and drowned..$^{31}$ In support of their theses, the sophists draw on examples from literature, just as Callicles invoking the song of Pindar on Heracles, who stole the cattle of Geryon by right of strength. ${ }^{32}$ Most certainly, the critical reflection over justice and the stimulus to radicalize views found the source also in the corruption and unjust decisions of the courts, in the functioning of the Athenian democracy during the Peloponnesian War, and in the tragic events of the said war during which Athenians gave examples of ruthlessness in thought and action, to mention just the cases of Mytilene and Melos. ${ }^{33}$ These observations provided numerous reasons to confirm the view that human actions are driven by highly egoistic motives.

${ }^{27}$ E. Zeller (1869, 921): "Entgegensetzung des natürlichen und positiven Rechts" is according to Zeller a "Lieblingssatz der späteren sophistischen Ethik".

${ }^{28} \mathrm{Pl}$., Gorg. 470cd: "Very well then, Socrates, there's no need to refute you with ancient affairs; for these things that happened just yesterday or the day before are sufficient to refute you and to show that many human beings who do injustice are happy." (transl. by J. H. Nichols, 55).

${ }^{29} \mathrm{Pl}$., Gorg. 484b. Callicles quotes Pindar: "And Pindar too seems to me to point to what I'm saying in the ode in which he says that "Law, the king of all mortals and immortals"; and this indeed, he says, "leads, making what is most violent just, with highest hand; I judge so from the works of Heracles, since-without payment-. . . ". (transl. by Nichols, 74).

${ }^{3 \circ} \mathrm{Pl}$., Gorg. 483de. "Both among the other animals and in whole cities and races of human beings, the just has been decided thus, for the stronger to rule the weaker and to have more. Indeed, making use of what kind of justice did Xerxes lead his army against Greece, or his father against the Scythians?" (translated by Nichols, 74).

${ }^{31}$ Pl. Gorg., 471ad.

${ }^{32} \mathrm{Pl}$., Gorg., 484b.

${ }^{33}$ See the cases of Mytilene in Thuc. (III 36 sq.) and Melos (V 83-116). W. K. C. Guthrie (1969) 19-2o. 
The already mentioned turn to nature induced the new generation of sophists to believe in a set of "natural" and thus objective and generally applicable determinants. In the view of the sophists, who might have been under the influence of Hippocratic medicine ${ }^{34}$, a man is a biological creature and a part of the world of nature.$^{35}$ As human actions are determined by the biological aspects of our nature - we are all born, strive to survive, and di $^{36}$ - every living being must in this situation compete with others to satisfy its needs. ${ }^{37}$ As a result of the unavoidable conflict of interests, a fight ensues which brings victory to the stronger individual.

The adherents of nature brought up three main arguments against culture and its order.

Firstly, culture, by blurring that what is natural, constitutes a source of inequality. It causes segregation based on criteria contrary to nature, dividing people into better and worse, as is the case with the difference in the status of all people, all the citizens ${ }^{38}$, men and women, freemen and slaves, ${ }^{39}$ aristocrats and common people, ${ }^{40}$ Greeks and barbarians..$^{41}$

Secondly, the established laws, the guardians of order, are very often changed ${ }^{42}$ and since they result from a contract, their validity is limited. They constrain people and hinder the accomplishment of the profit, which is of supe-

\footnotetext{
${ }^{34}$ G. B. Kerferd (1981) 51; 57-58; 158.

${ }^{35}$ W. Nestle (1940) 285 .

${ }^{36}$ See, e.g. the opening words of Gorgias' Defence of Palamedes speech (DK 82 B 11a1)
} and Antiphon's On Concord (DK 87 B 44), cf. R. Waterfield (2000) 259: "Self-preservation, Antiphon implies, is the ultimate natural law, and a great deal of his critique of society stems from this: self-preservation requires one to obey unnatural laws when others are watching; pain and discomfort are criteria by which we can judge that something is bad for us, and tends against self-preservation, and by these criteria human laws are bad, since they cause us pain."

${ }^{37}$ DK 87 B 44 col. 2.

${ }^{38}$ Hippias in Pl., Prot., 337cd = (DK 86 C 1).

${ }^{39}$ J. Dillon, T. Gergel (2003) 293: Alcidamas of Alaea: “God left all men free; Nature has made no man a slave” (Anonymous, in Rhetorica Aristotelis, CAG 21: 2, p 74 Rabe).

${ }^{40}$ K. Freeman (1947) 139: Lycophron "the Sophist" (DK 83 4): "The beauty of high birth is hidden, its dignity merely a matter of words."

${ }^{41}$ R. Waterfield (2000) 264: Antiphon the Sophist (F17 = DK 87 B 44b $\dagger$ ): "This has led to our behaving like foreign savages towards one another, when by nature there is nothing at all in our constitutions to differentiate foreigners and Greeks."

${ }^{42}$ Xenophon, Mem. IV. IV. 14, 1-4 "Laws, said Hippias, can hardly be thought of much account, Socrates, or observance of them, seeing that the very men who passed them often reject and amend them." (trans. by E.C. Marchant, 315-317). 
rior value as indicated by nature itself. ${ }^{43}$ Due to the limited validity of laws, any violation involves the evil of penalty only when the violating act comes to light. ${ }^{44}$

Thirdly, culture enforces upon man permanent hypocrisy and conformism, making him create an illusion of being just and honest. Thus, culture obscures the truth about man by hiding his true essence, which gets manifested when the lights are out or, as in the story of Gyges, when a man can wear a ring of invisibility. ${ }^{45}$ Life in accordance with laws and customs does not pay, and those who are unjust but dress as righteous prevail.

What becomes fundamental for this way of thinking is the antithesis of evident and obscure and the observation that the other hidden agenda plays in both private and public life a much more important role than the evident one. Not only does culture prove to be susceptible to deception, but - what is more - it generates it itself. ${ }^{46}$ In human reality across all its planes appearances clash with appearances and the winner of the sham contest is the one who is more skilled in pretending. So, culture condemns man to permanent hypocrisy forcing him to

${ }^{43} \mathrm{R}$. Waterfield (2000) 265: Antiphon the Sophists (F $18=$ DK 87 B 44 A col. 4.): "This is exactly what this investigation of mine is concerned with - to show that most of the actions sanctioned by law are inimical to nature. For laws dictate what the eyes may and may not see, what the ears may and may not hear, what the tongue may and may not speak, what the hands may and may not do, where the feet may and not go, and what the mind may and may not desire. There is no difference between the things the laws deter us from doing and the things the laws encourage us to do: both are equally inimical to nature. For what is natural is life and death, and life comes about through things which are advantageous, while death comes about from things which are disadvantageous. The advantages offered by the law are fetters on nature, but the advantages offered by nature bring freedom."

${ }^{44}$ R. Waterfield (2000) 264-5: Antiphon the Sophist (F $18=$ DK 87 B 44 A): "Justice, therefore, is conforming to the rules and regulations of the community of which you are a citizen. The way to gain maximum advantage for yourself from justice, then, to treat the laws as important when other people are present, but when there is nobody else with you to value the demands of nature. For the laws' demands are externally imposed, those of nature are essential, and while agreement, not nature, has produced the laws' demands, nature, not agreement, has produced those of nature. So if your transgression of regulations escapes the notice of those who have made the agreement, you avoid both shame and punishment, but incur them if it doesn't; however, if you achieve the impossible and violate one of the inherent demands of nature, the harm you suffer is not decreased if what you do goes totally unnoticed, and not increased if everyone sees you, because it is genuine harm, a result of what others think of you."

${ }^{45} \mathrm{Pl}$., Resp., 359cd.

${ }^{46}$ See the significance of the motif of deception, e.g. in Gorgias' doctrine of craft (techne) in W. J. Verdenius (1981) 116-28. 
suppress the natural. It thus conceals the true face of man, depriving him of the possibility to realize his nature.

Ironic as it may sound, from this perspective the supporters of the "right of the stronger" act as the advocates calling for honesty to be reconstituted in relations among men. In the name of those principles, they demand hypocrisy be discarded by legitimizing the natural human inclination to deception. They also require the introduction of standards and values adequate to the true human nature, which means standards and values that reduce everything to the ultimate goal of profiting and achieving an advantage. Particular emphasis is placed on getting rid of the sense of shame, which in their opinion is something completely alien to the world of nature, a product of culture imposing invisible constraints on mankind. As in the case of gods, who, according to the poem attributed to Critias, were invented by a prudent ruler to restrain and control people in situations where they escape the human control, ${ }^{47}$ shame plays the role of a fictional guardian of culture supervising the sphere of life which remains obscure.

The above essay is just an outline of the then considerations concerning the essence of man centred around the antithesis of nature and culture. The synthetic and concise form of this presentation does not convey the most crucial aspects, namely the emotions and attitudes related to the views and opinions propagated, which are always closely connected with historical context, with specific figures and events under the influence of which the views and opinions were forged. However, it seems to me that the general nature of this presentation reflects the timeless character of the discussion, while the views presented may provide a universal framework for the debate, which has continued throughout the development of the European culture and is unlikely to end soon.

\section{REFERENCES}

Aly, W. (1929) Formprobleme der frühen griechischen Prosa. Leipzig. Diels H., W. Kranz (1968, 14th ed) Die Fragmente der Vorsokratiker. Dublin/Zürich.

Diels, H. (1884) "Gorgias und Empedokles," Sitzungsberichte der königlich preussischen Akademie der Wissenschaften zu Berlin, 343-68.

Dihle, A. (1981) "Die Verschiedenheit der Sitten als Argument ethischer Theorie", Kerferd

G. B., ed. The Sophists and Their Legacy. Wiesbaden, 56-63.

Dillon, J., Gergel T., eds. (2003) The Greek Sophists. London.

Dodds, E. R. (1973) The Ancient Concepts of Progress. Oxford.

Dupréel, E. (1948) Les Sophistes. Protagoras, Gorgias, Prodicus, Hippias. Neuchâtel.

Farrar, C. (1988) The Origins of Democratic Thinking. Cambridge.

\footnotetext{
${ }^{47}$ G. B. Kerferd (1981) $5^{2-3}$.
} 
Freeman, K., (1947) An Ancilla to The Pre-Socratic Philosophers: A Complete Translation of the Fragments of Diels, Fragmente Der Vorsokratiker. Cambridge, Massachusets.

Guthrie, W.K.C. (1969) A History of Greek Philosophy. Vol. 3. The Fifth-Century Enlightenment, Cambridge.

Heinimann, F. (1945) Nomos und Physis. Basel.

Heinimann, F. (1961) "Eine vorplatonische Theorie der Technē," Museum Helveticum 18, 105-30.

Jaeger, W. (1971, vol. 3, 2nd ed) Paideia. The Conflict of Cultural Ideals in the Age of Plato. New York - Oxford.

Jansen, L., Jedan, Ch., eds. (2010) Philosophische Anthropologie in der Antike. Frankfurt.

Kerferd, G. B., (1981) The Sophistic Movement. Cambridge.

Kube, J. (1969) Techne und arete; sophistisches und platonisches Tugendwissen. Berlin.

Nestle, W., (1922) Die Vorsokratiker. Jena.

Nestle, W., (1940) Vom Mythos zum Logos. Stuttgart.

Plato. Gorgias (1998) Translated by J. H. Nichols. Ithaca, NY.

Plato. Theaetetus. Sophist (1921) Translated by H. N. Fowler. Cambridge, Massachusets.

Sihvola, J. (1989) Decay, Progress, the Good Life? Hesiod and Protagoras on the Development of Culture. Helsinki.

Verdenius, W. J. "Gorgias' Doctrine of Deception," G. B. Kerferd ed., The Sophists and Their Legacy, Wiesbaden, 116-28.

Waterfield, R., (2000) The First Philosophers. The Presocratics and Sophists. Oxford.

Windelband, W. (1901) A History of Philosophy. New York.

Winton, R., "Herodotus, Thucydides and the Sophists," Rowe, Ch., Schofield, M., Harrison, S., Lane, M., eds. (2008) The Cambridge History of Greek and Roman Political Thought, Cambridge, 89-121.

Xenophon. Memorabilia. Oeconomicus, Symposium, Apology (1997) Translated by E. C. Marchant, O. J. Todd. Cambridge, Massachusets and London.

Zeller, E. (1869) Die Philosophie der Griechen in ihrer geschichtlichen Entwicklung. Vol. I, 3rd ed. Leipzig.

Zilioli, U. (2007) Protagoras and the Challenge of Relativism: Plato's Subtlest Enemy. Aldershot. 